\title{
1分値地上観測雨量データを用いた都市中小河川 流域におけるXバンドMPレーダ雨量の精度評価 PRECISION EVALUATION OF X-BAND MP RADAR RAINFALL IN A SMALL URBAN WATERSHED BY COMPARISON TO 1-MINUTE GROUND OBSERVATION RAINFALL DATA
}

\author{
米勢嘉智 1 ・河村明 2 ・天口英雄 3 ・ 戸野塚章宏 4 \\ Yoshitomo YONESE, Akira KAWAMURA, Hideo AMAGUCHI and Akihiro TONOTSUKA \\ 1正会員 工修（株）建設技術研究所（干103-8430 東京都中央区日本橋浜町3-21-1） \\ 2正会員 工博 首都大学東京教授 都市環境科学研究科（干192-0397 東京都八王子市南大沢1-1） \\ 3正会員 工博 首都大学東京助教 都市環境科学研究科（干192-0397 東京都八王子市南大沢1-1） \\ 4学生会員 首都大学東京 都市環境学部（干192-0397 東京都八王子市南大沢1-1）
}

\begin{abstract}
Under the frequent floods caused by localized concentrated heavy rainfall, it becomes considerably important to achieve detailed rainfall, especially localized concentrated heavy rainfall in a small urban watershed. X-band MP-radar, providing space-time distribution rainfall data, is expected to be made effective use of its advanced detailed data, while few studies on the precision evaluation of 1-minute Xband MP radar data were conducted. This paper discusses results on the precision evaluation of X-band MP radar data by comparison to 1-minte ground observation rainfall data, installed in high density at the upper basin of Kanda river in Tokyo. The results showed that 1-minute data of X-band MP radar realized detailed space and time scale rainfall distribution, though it was hardly met by 10 -minutes data, and sufficiently described localized concentrated heavy rainfall in a small urban watershed.
\end{abstract}

Key Words : 1-minute data, X-band MP radar, XRAIN, ground observation rainfall data, small urban watershed, Kanda river

\section{1. はじめに}

近年，ゲリラ豪雨と呼ばれる局地的な集中豪雨により 洪水被害が頻発している．特に首都圈においては，人口 や生産基盤等の集中，都市化や気候変動等に起因した洪 水流量の増大などの社会・環境条件により水害リスクが 一層増大している. 都市域の中小河川では，短時間にお ける集中豪雨により，河川の汇濫や内水による浸水被害 の危険性が高いため, 都市流出解析では詳細な1分值降 雨や水位観測データを用いた流出解析が行われている1),2) このような流出解析による河川水位の推定のためには, 第一に詳細な降雨の空間・時間分布を的確に把握するこ とが重要となる.

国土交通省が整備するXバンドMPレーダネットワー ク（XRAIN）は，2010年からの試験運用期間を経て 2014年3月に本格運用を開始し, 詳細な降雨の時空間分 布の情報が入手できる環境が整備されている。レーダに よる降雨観測特性や高精度な降雨量推定についての研究
も進められてきており，XバンドMPレーダ雨量の精度 向上が図られている3) 5).また，XバンドMPレーダによ る解像度の高い降雨観測データを活用した取り組みとし ては，地上雨量観測所による降水量および降雪量推定精 度の検証吕や, 名古屋地区における雨域解析による地上 雨量計との比較7), 時間分解能の長い降水イベントにお ける降雨量推定や詳細な空間精度に関する検証)などが 挙げられる。これらはレーダ雨量における観測特性を活 かして, 数十 $\mathrm{km}^{2}$ 程度の比較的広域を対象としているも のが多い. 小流域における研究事例 ${ }^{9)} と し て は ， 二$ 級河 川流域（21 $\mathrm{km}^{2} ）$ を対象とした精度検証が行われ，空間 的な変動が大きい局地豪雨において, 地上雨量計による 流域平均降雨とXバンドMPレーダ雨量との差が大きく なることが指摘されている.

上述したXバンドMPレーダ雨量の精度検証では, 地 上雨量の観測時間間隔との整合にも考慮して1分間隔の 観測データを10分值などに換算したものを用いている. しかし, 都市域の中小河川のような詳細なエリアを対象 
とする場合には，より短い時間間隔における降雨量の精 度が重要となるため1分データそのものの精度評価を把 握しておくことが重要となる。しかし，そのような精度 検証を行った既往の研究事例は見受けられない.

本研究では，東京都の代表的な都市中小河川である神 田川上流域における2013年の豪雨として10イベントを抽 出し, 東京都に高密度に配置された地上降雨観測データ

（東京都水防災総合情報システム）における雨量值を基 準とした比較によるXバンドMPレーダの精度評価を実 施した.

\section{2. 対象流域および対象降雨}

検証対象流域とする神田川は，東京都三鷹市の井の頭 池にその源を発し，中野区の区境付近で善福寺川と合流 し，新宿区に流入する流域面積 $105.0 \mathrm{~km}^{2}$ ，流路延長 $25.48 \mathrm{~km}$ の東京都内の中小河川としては最大規模の一級 河川である ${ }^{10)}$. 本論文では, 図-1に示寸神田川の井の頭 池から善福寺川合流点までの上流域約 $11.5 \mathrm{~km}^{2}$, 流路延 長約 $9 \mathrm{~km}$ 対象流域として設定した.

使用寸る地上雨量観測所は，東京都水防災総合情報シ ステムによる地上雨量観測データを用いた. 対象流域付 近における観測所は図-2に示寸とおりである.ティーセ ン分割法による流域内の1観測所あたりの支配面積は平 均で $1.3 \mathrm{~km}^{2}$ 程度, 最大でも $3 \mathrm{~km}^{2}$ 以下と, 非常に高密度に 配置されており，これらの観測所毎に1分間隔，最小単 位1 $1 \mathrm{~mm}$ にて雨量データを計測している.

検証対象降雨は，2013年に発生した降雨から対象流域 に豪雨をもたらした降雨を対象として抽出することとし た. 中小河川では, 短時間の強降雨が河川水位を上昇さ せる. 平成20年の都賀川水害の例では7月28日14:30〜 15:00の30分に流域周辺に強い降雨が発生し, 河川水位 は10分間で $1.34 \mathrm{~m} も$ 急激な上昇を示している．そのた め, 検証対象降雨イベントの抽出にあたっては，対象流 域中央付近に位置し水位観測も実施している久我山橋観 測所を対象として，30分累加雨量值が10mm以上の豪雨 として表-1に示す10イベントを抽出した. なお，一降雨 イベントは，6時間以上の無降水状態を伴わない一連の 降雨を一降雨として設定した ${ }^{11)}$.また, 表-1には, ティーセン分割法による流域平均総雨量の一降雨総雨量, 検証降雨期間, 降雨要因についても示した.

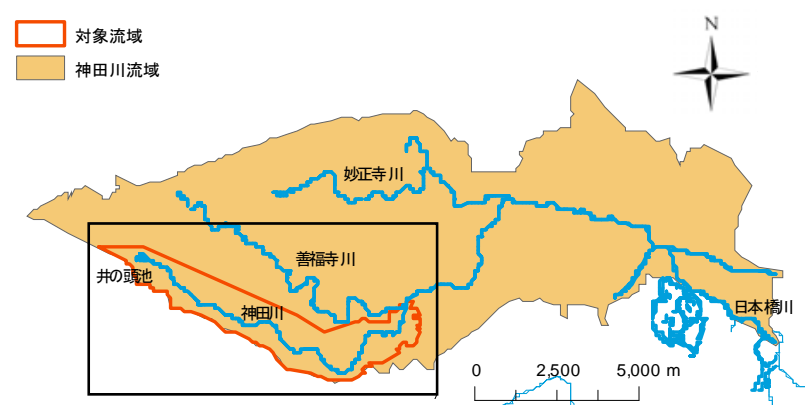

図-1 対象とした神田川上流域位置

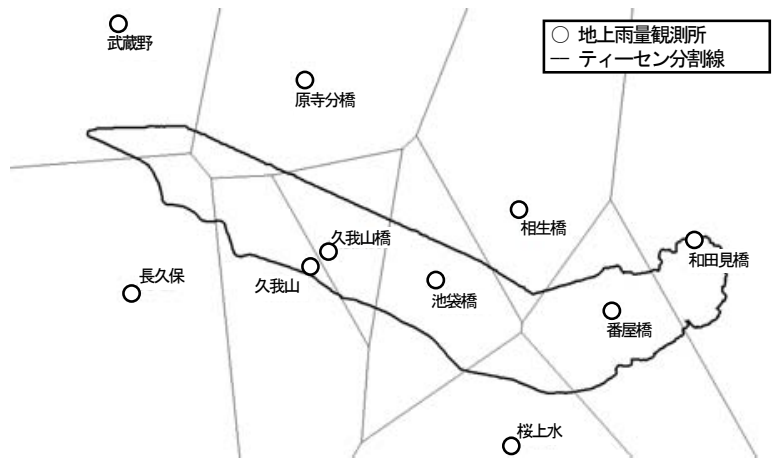

図-2 対象流域の地上雨量観測所とティーセン分割

\section{3. 地上雨量データとXバンド雨量データの特性}

対象流域におけるXバンドMPレーダ雨量の精度を把 握するため, 流域内に存在する5箇所の地上雨量観測所 （久我山，久我山橋，池袋橋，番屋橋，和田見橋）の各 地上雨量と当該観測所メッシュにおけるXバンドMP レーダ雨量をもとに精度を検証した，図-3には，降雨イ ベントNo.1に対する久我山橋, 池袋橋, 番屋橋観測所の 地上雨量とXバンドMPレーダ雨量のハイエトグラフお よび総雨量の比較図を示した。また，同図にはRMSE (平均二乗誤差の平方根) とともに「9/5 7:00 9:00」 の拡大図も示した. 図-3より, 地上雨量観測データは, 最小単位が1mmであり, かつ単位をmm/hrに換算してい るため, XバンドMPレーダ雨量と比べてと值の変動が 大きくなっている. 本降雨イベントNo.1は，9/5 0:00〜 1:30の小降雨後5:00〜6:00に 1 山目, 7:30〜8:30に 2 山目 の降雨が発生する降雨波形を示しているが，Xバンド MPレーダをみると地上雨量において観測しているタイ ミングとほぼ同じかやや早い時間帯に降雨を観測してい る. また, 累加雨量でみると, 久我山橋では2割程度の

表-1 選定した降雨イベント

\begin{tabular}{|c|c|c|c|c|c|c|c|c|c|}
\hline \multirow{2}{*}{$\begin{array}{c}\text { 降雨イベント } \\
\text { No. }\end{array}$} & \multicolumn{2}{|c|}{ 30分累加雨量 (久我山橋) } & \multicolumn{3}{|c|}{ 一降雨継続時間および流域平均総雨量 } & \multicolumn{3}{|c|}{ 検証降雨期間 } & \multirow[b]{2}{*}{ 降雨要因 } \\
\hline & 抽出開始時間 & $\begin{array}{l}\text { 雨量 } \\
(\mathrm{mm})\end{array}$ & 降雨開始時刻 & \begin{tabular}{|l|} 
降雨継続時 \\
間(時:分) \\
\end{tabular} & $\begin{array}{c}\begin{array}{c}\text { 総雨量 } \\
(\mathrm{mm})\end{array} \\
\end{array}$ & 開始時刻 & 終了時刻 & $\begin{array}{c}\text { 時間 } \\
(\mathrm{hr})\end{array}$ & \\
\hline 1 & $2013 / 09 / 0507: 44$ & 32 & $2013 / 09 / 0421: 11$ & $13: 46$ & 66.3 & $2013 / 09 / 0421: 00$ & 09/05 11:00 & 14 & 低気压 \\
\hline 2 & $2013 / 06 / 2512: 22$ & 32 & $2013 / 06 / 2507: 33$ & $7: 07$ & 39.7 & $2013 / 06 / 2507: 00$ & $06 / 2515: 00$ & 8 & 大気状態不安定 \\
\hline 3 & $2013 / 08 / 1217: 53$ & 31 & $2013 / 08 / 1217: 44$ & $12: 54$ & 44.3 & $2013 / 08 / 1217: 00$ & $08 / 1307: 00$ & 14 & 大気状態不安定 \\
\hline 4 & $2013 / 09 / 1506: 49$ & 30 & $2013 / 09 / 1503: 50$ & $17: 31$ & 135.2 & $2013 / 09 / 1503: 00$ & $09 / 1522: 00$ & 19 & 台風18号 \\
\hline 5 & $2013 / 07 / 23 \quad 15: 45$ & 25 & $2013 / 07 / 23 \quad 15: 36$ & $2: 55$ & 21.2 & $2013 / 07 / 23 \quad 15: 00$ & $07 / 23 \quad 19: 00$ & 4 & 大気状態不安定 \\
\hline 6 & $2013 / 10 / 16$ 03:42 & 19 & $2013 / 10 / 1511: 48$ & $19: 40$ & 195.6 & $2013 / 10 / 1511: 00$ & $10 / 1608: 00$ & 21 & 台風·停滞前線 \\
\hline 7 & $2013 / 08 / 2115: 55$ & 16 & $2013 / 08 / 21 \quad 15: 36$ & $6: 40$ & 17.9 & $2013 / 08 / 21 \quad 15: 00$ & $08 / 2123: 00$ & 8 & 前線 \\
\hline 8 & $2013 / 04 / 0622: 41$ & 16 & $2013 / 04 / 06 \quad 15: 18$ & $11: 36$ & 88.7 & $2013 / 04 / 06 \quad 15: 00$ & 04/07 03:00 & 12 & 低気圧 \\
\hline 9 & $2013 / 08 / 2623: 48$ & 12 & $2013 / 08 / 2622: 33$ & $9: 40$ & 45.1 & $2013 / 08 / 2622: 00$ & $08 / 2709: 00$ & 11 & 前線 \\
\hline 10 & $2013 / 08 / 1115: 16$ & 11 & $2013 / 08 / 1115: 01$ & $0: 46$ & 8.0 & $2013 / 08 / 1115: 00$ & $08 / 1116: 00$ & 1 & 大気状態不安定 \\
\hline
\end{tabular}




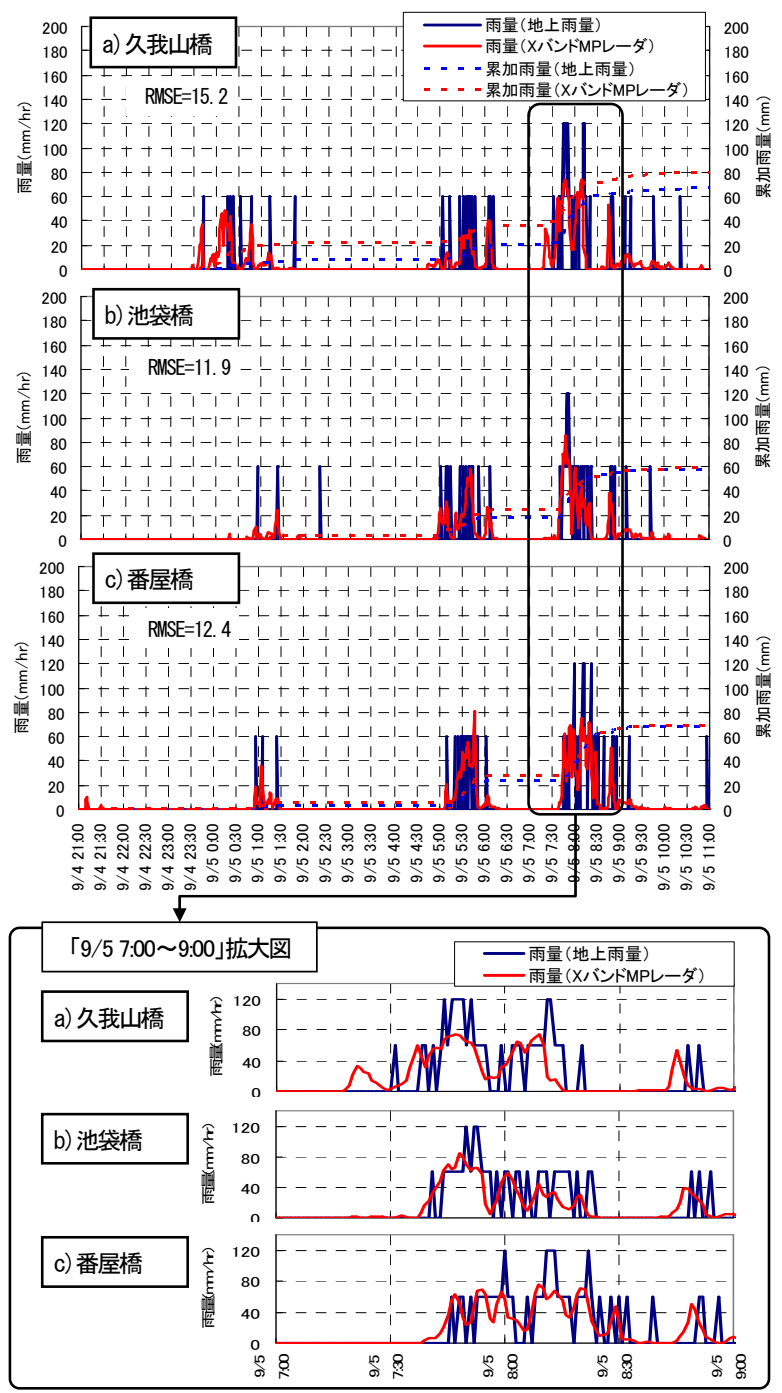

図-3＼cjkstart地上雨量・XバンドMPレーダハイエトグラフ 比較図（降雨イベントNo. 1)

差があるものの再現性は概ね良好といえる.

なお, 総雨量ボリュームの精度評価には，既往研究3) などでも使用されている基礎的指標である総雨量比（X バンドMPレーダ総雨量／地上雨量総雨量）を用いて整 理する. 総雨量比の1.0から2割程度の乘離は，既往研究 においても認められる差の範囲内である.

図-4 a),b)には，各降雨イベントの総雨量比および1 分雨量值の相関係数を示す.この図より，和田見橋では 大きめの総雨量比，低めの相関係数といった傾向が見受 けられるものの, 必ずしも明確な傾向は確認できない. 一方, 降雨イベント毎の総雨量比をみると, 総雨量比が 1.0に近い降雨イベントとして, No.1, No.4, No.6, No.8 が挙げられるが，これらは，台風性もしくは低気圧によ る降雨イベントであり，降雨期間が長くかつ総雨量が大 きい降雨となっている. すなわち, 降雨量が大きい場合 には，総雨量比の精度が確保しやすい傾向があると考え られる. 図-4 b) より，降雨イベント毎の1分雨量值の相 関係数をみると, 降雨イベントおよび地点間のばらつき はみられるが, 降雨イベントNo.1〜No.5は相関が高く，

No.6以降になるにつれて相関係数の值が低下する傾向が

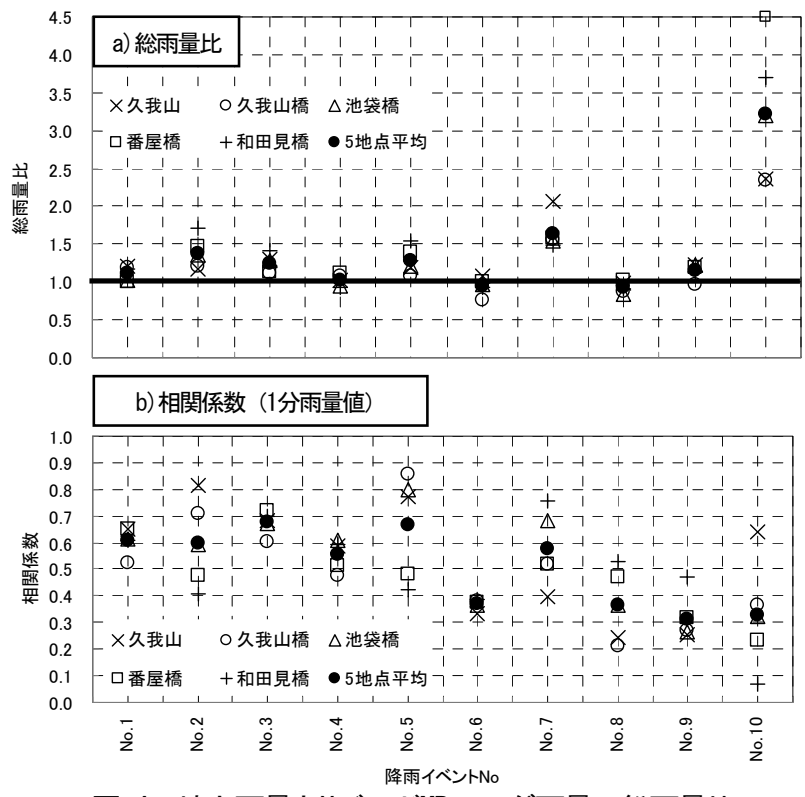

図-4 地上雨量とXバンドMPレーダ雨量の総雨量比 (XバンドMPレーダ雨量/地上雨量) と相関係数

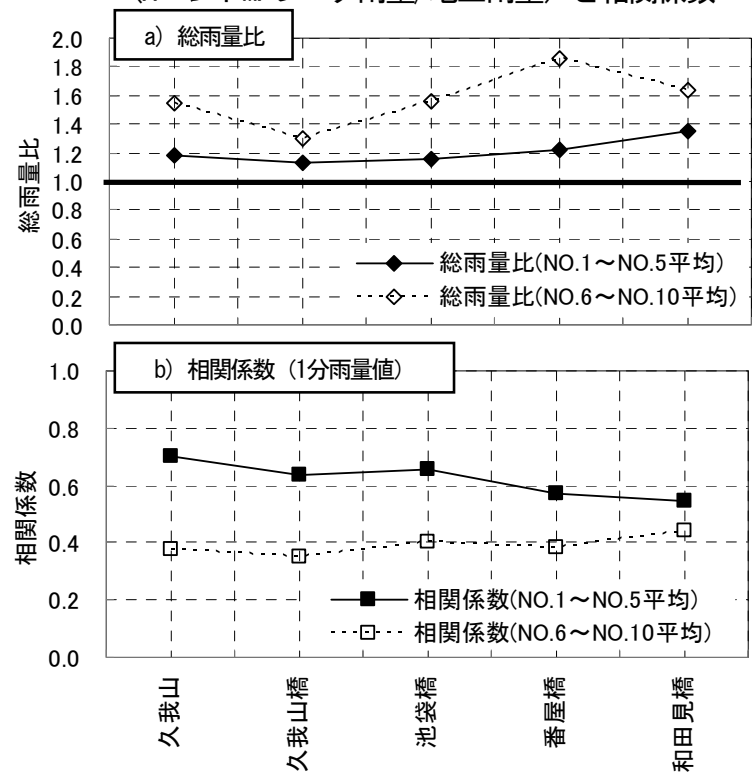

図-5＼cjkstart降雨イベントNo. 1〜5と№. 6〜10の総雨量比および 1分雨量値の相関係数

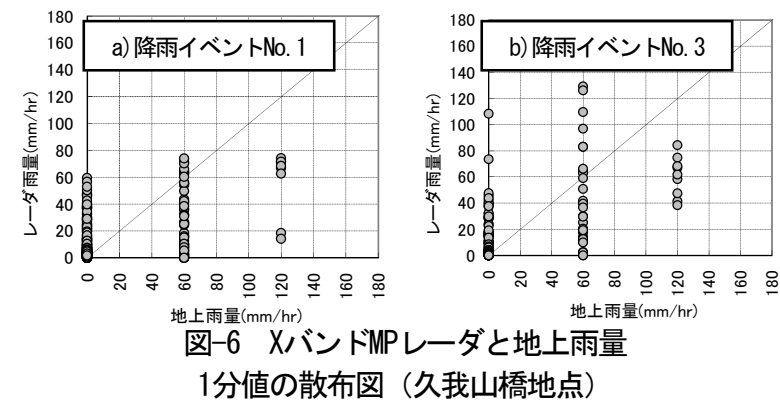

みられる. No.3, No.5, No.7は，前線や大気状態不安定 に起因する降雨イベントであり，相関係数が相対的に高 く降雨波形を良くとらえていると判断できる.

次に，図-5 a),b)は，30分雨量の大きい降雨イベント No.1〜No.5と比較的小さいNo.6〜No.10に分けて, 総雨 量比と 1 分雨量值の相関係数を示したものである. 図 -5 a)より総雨量比についてみると, 降雨イベント 
No.1 No.5の平均值は約1.21, No.6 No.10の平均值は約 1.59であり，30分雨量が大きい場合は総雨量比が1.0に近 い. 図-5 b) より, 降雨イベントNo.1 No.5平均值で0.62, No.6 No.10平均值で0.39となり，いずれも相関が低い結 果となった。 XバンドMPレーダは地上雨量による降雨 発生タイミングを概ねとらえていると考えられるが，こ れは，図-6の散布図に示すように地上雨量の観測最小単 位が1mmであるため，滑らかな值の変動がとらえられず 值に段差ができ，相関係数が低下する要因となったと考 えられる.

\section{4. 流域平均雨量を用いたXバンドMPレーダ雨量 精度の評価 \\ （1）1分値データによる精度評価}

対象流域における1分值による流域平均雨量について 精度検証を行った。 地上雨量による流域平均雨量は, ティーセン分割法により算出し，XバンドMPレーダ雨 量による流域平均雨量は, 図-7に示す流域メッシュ範囲 における平均雨量とした。

図-8は，XバンドMPレーダおよび地上雨量により算 出した流域平均雨量による総雨量を, 図-9には降雨イベ ントNo.1〜No.5のXバンドMPレーダ雨量によるメッシュ 累加雨量図を示す. 図-9より，No.1やNo.4などの上流域 多雨のものやNo.2のように中流域多雨降雨のものなど, 小規模な流域であるが降雨の分布は一様ではなく差が大 きいことがわかる。また、図-8よりXバンドMPレーダ と地上雨量の総雨量は，雨量が小さい場合に多少ばらつ きが見られるものの概ね一致しており，様々な降雨の降 り方においても総雨量は適切に把握できていると考えら れる.

次に，図-10には，地上雨量およびXバンドMPレーダ 雨量による流域平均雨量のハイエトグラフを示す。これ より地上雨量による流域平均雨量は，観測所毎の地上雨 量に比べて值の変動が抑えられており，XバンドMP

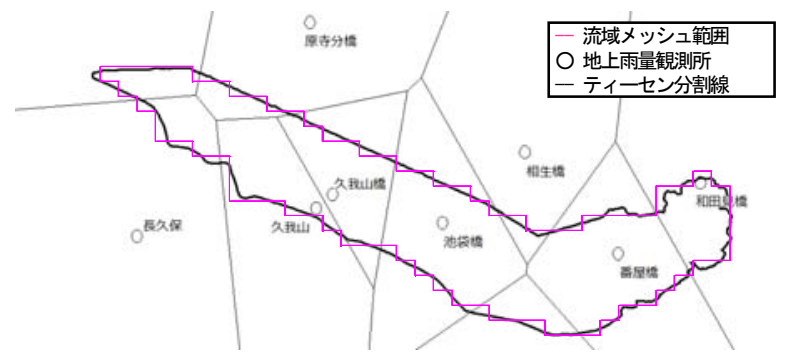

図-7 対象流域のメッシュエリア
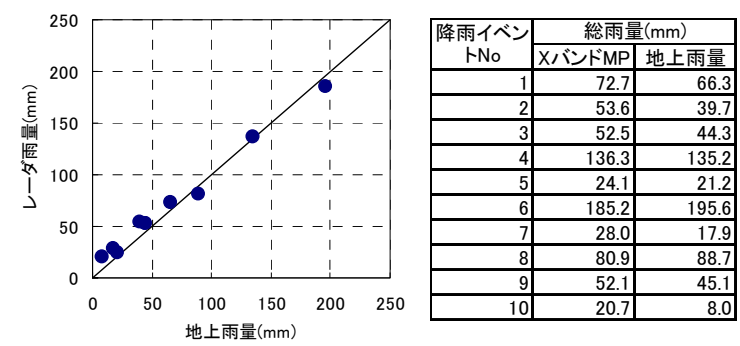

図-8＼cjkstart降雨イベント毎のXバンドMPレーダと地上 雨量による流域平均総雨量
レーダ雨量と地上雨量は，ほぼ同様の降雨波形を表現で きているといえる.

図-11 a),b)には，それぞれ流域平均雨量による降雨 イベント毎の総雨量比および1分雨量值の相関係数を示 した，総雨量比に関しては，前述した観測所毎の総雨量 比と同様, 総雨量が大きいほど総雨量比は1.0に近い值 となる. なお， 総雨量が小さい降雨イベントNo.10を除 いたNo.1 No.9の総雨量比の平均值は1.15であり, 良好 な精度を確保していると判断できる.

図-11 b) より，流域平均雨量による1分雨量值の相関 係数は，降雨イベントNo.1〜No.5の平均值として0.88, No.6 No.10は0.71である.これらは，5地点平均の相関 係数（No.1 No.5平均值で0.62） と比較して，大幅に高 い值となっている。 これは，図-12の流域平均雨量1分值 の散布図に示すように，図-6にみられた地上雨量観測の 最小単位1mmの段差が平均化され滑らかな波形となった ことが主要因であると考えられる.

次に，図-10 e)の降雨イベントNo.5をみると，Xバン ドMPレーダ雨量は地上雨量よりも3分程度早く降雨を観 測しており，降雨波形に位相差がみられる。他の降雨イ ベントにおいてもNo.5ほど差は顕著ではないものの，X バンドMPレーダ雨量は地上雨量より 1 分程度早い傾向が 見られる.この観測時差は，レーダ観測高度から地上雨 量計に到達するまでの雨滴落下時間が主要因と推測され る. 例えば，一般的に，XバンドMPレーダで上空 $600 \mathrm{~m}$ を観測し，観測した降雨が $50 \mathrm{~mm} / \mathrm{hr}$, 雨滴直径 $2 \mathrm{~mm}$ 程度, 落下速度は6.6m/sとすると, 地上までの落下時間は約 1.5 分となる.

しかし，降雨イベントNo.5を詳細に調べると，流域中 央部のみで降雨強度 $100 \mathrm{~mm} / \mathrm{hr}$ を超える豪雨が発生して おり，非常に局所的な積乱雲と強い上昇気流の発生によ り，特に流域周辺部において雨滴落下時間が長くなった と推察される.なお，これら観測時差については10分間 隔の降雨データでみた場合や流域からの流出時間で考え た場合にそれほど問題とならない場合もあるが，今後，
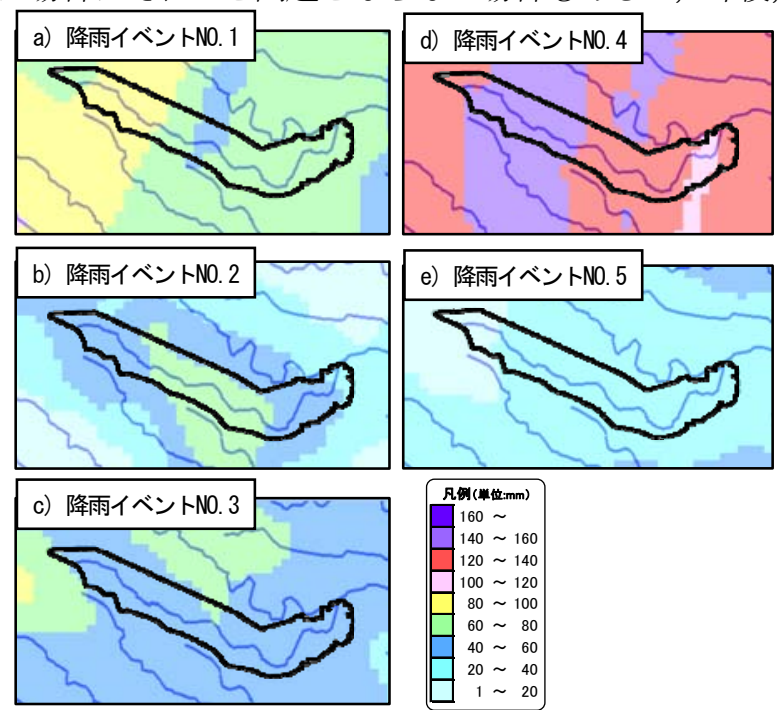

図-9ＸバンドMPレーダによるメッシュ累加雨量図 

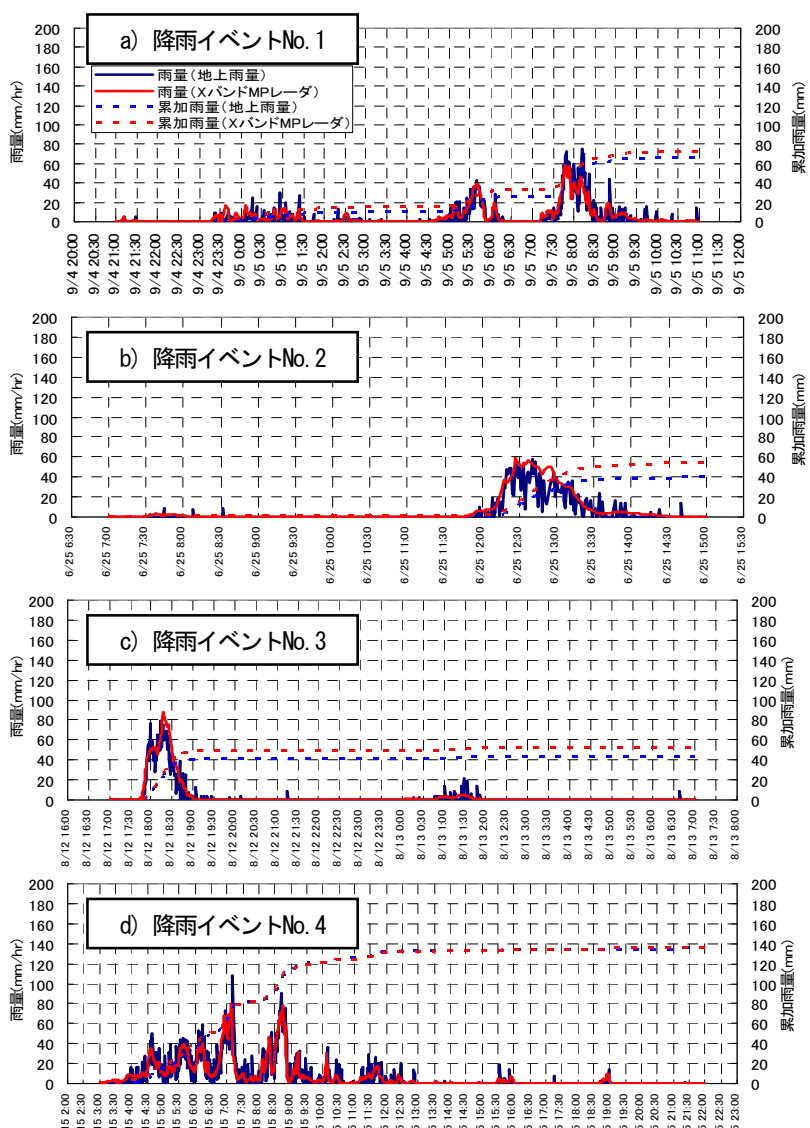

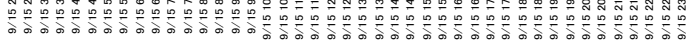

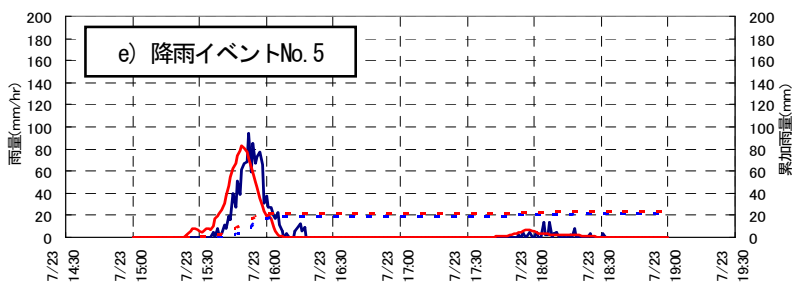

図-10 流域平均雨量1分值（地上雨量・XバンドMPレー ダ）のハイエトグラフ比較図

XバンドMPレーダ雨量をより詳細な時空間情報として 取り扱っていく場合には注意が必要である.

\section{（2）10分値データによる精度評価}

これまで降雨データを評価する場合には，地上雨量 データの観測時間間隔に合わせて10分雨量等を用いるこ とが多いため, 地上雨量およびXバンドMPレーダ雨量 を10分間隔データとした場合について精度を確認した。 10分值データは，1分值データを元に作成した. 図-13に は，地上雨量およびXバンドMPレーダ雨量による10分 值流域平均雨量のハイエトグラフについて, 降雨イベン トNo.1〜No.5のうち30分累加雨量が最大のNo.1 と総雨量 が大きいNo.4を示した. これより，10分值による両者の 降雨波形は，1分值の場合（図-10）と比較して相似性が 高くなっている.

図-14には，地上雨量とXバンドMPレーダ雨量の10分 值流域平均雨量の相関係数を，1分值流域平均雨量の相 関係数とともに示す.これより，10分值流域平均雨量は, 1分值のそれと比較し, 全ての降雨イベントにおいて,

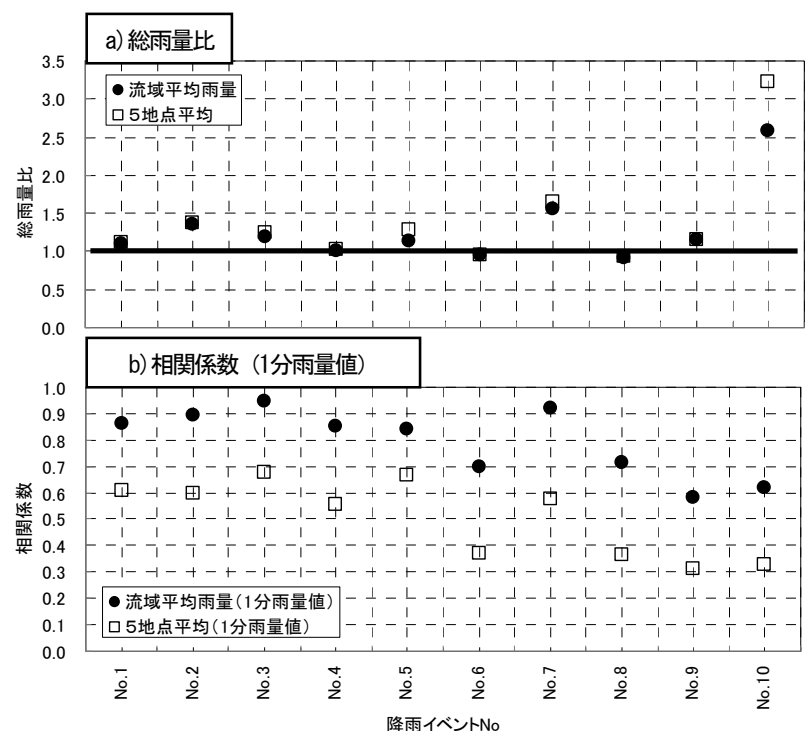

図-11 流域平均雨量における総雨量比 (XバンドMPレーダ雨量/地上雨量) と相関係数

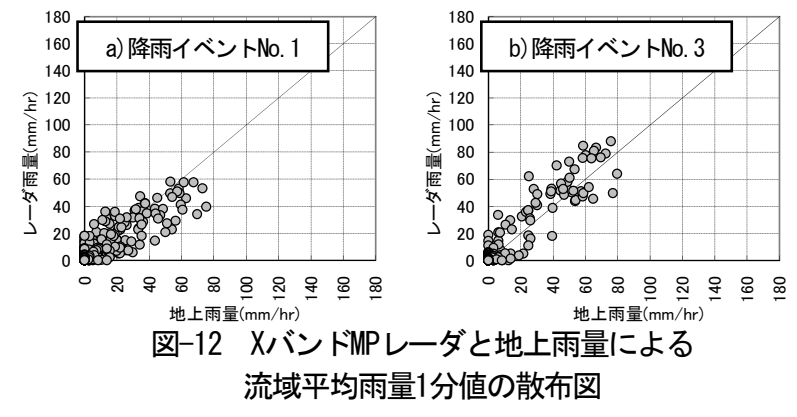

高い相関を示す值となった. これは，10分データを用い た場合，データが平滑化され1分データ（図-10）でみら れた降雨波形の詳細な差異が認識できなくなっているた めである.

\section{(3) XバンドMPレーダの1分値と10分值雨量の差異}

XバンドMPレーダ雨量による1分值と10分值雨量の差 異について，降雨波形からそれぞれの特徵を分析した.

図-15は，降雨イベントNo.1の流域平均雨量における2山 目期間（9/5 7:00〜10:00）を示したものである. 地上雨

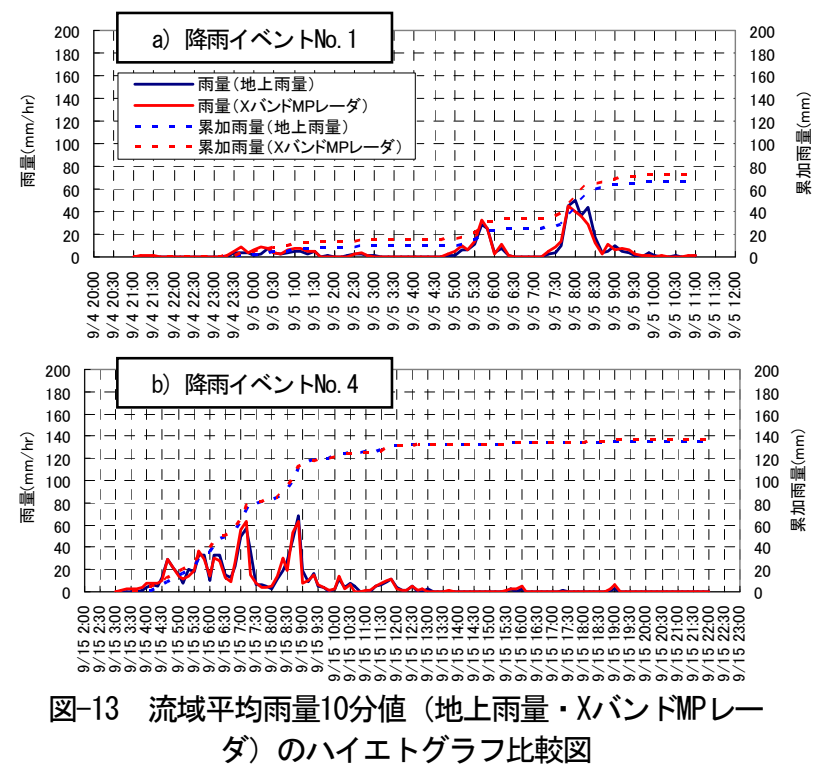




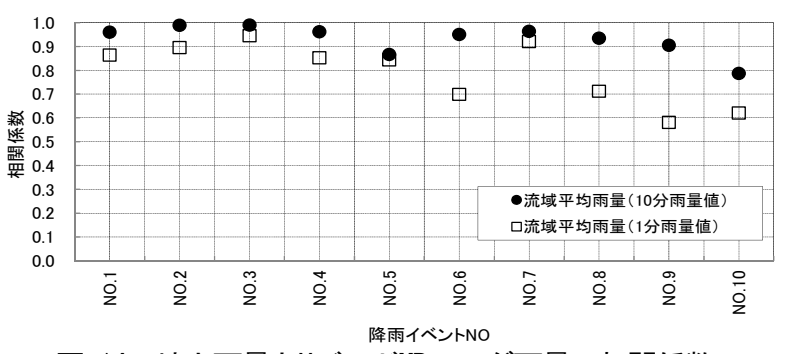

図-14 地上雨量とXバンドMPレーダ雨量の相関係数

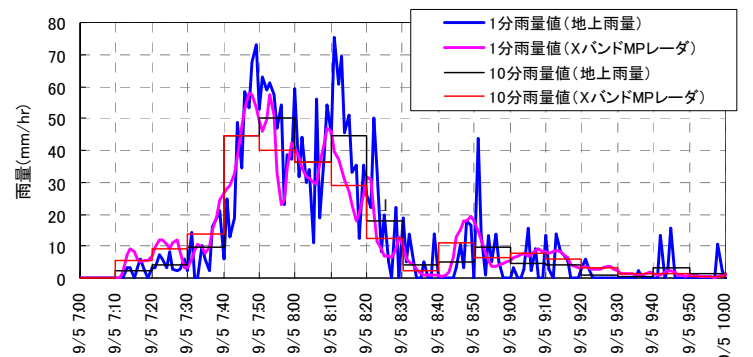

図-15 降雨イベントNo.1 (後半)の流域平均雨量の比較図

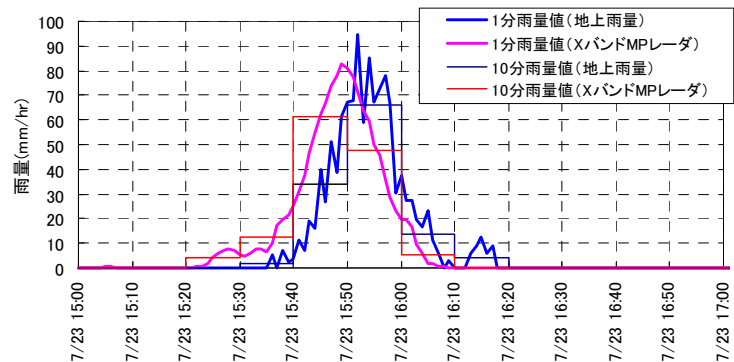

図-16 降雨イベントNo. 5 の流域平均雨量の比較図

量による流域平均1分值では，7:50付近でピーク雨量 70mm/hrとなっているが，流域平均雨量10分值でみると XバンドMPレーダ，地上雨量ともに平滑化されピーク が低減していることがわかる.

次に，図-16には，XバンドMPレーダ雨量と地上雨量 の観測時差が大きかった降雨イベントNo.5の流域平均雨 量を示した。 降雨イベントNo.5は，短時間における一山 降雨波形であり，流域平均雨量10分值では，Xバンド MPレーダ，地上雨量ともにピーク雨量が低減しており， 鋭敏な降雨波形の情報は失われていることがわかる。ま た，1分值のXバンドMPレーダと地上雨量の約3分の観 測時差が，10分值でみると10分の差として表れている. 降雨イベントNo.5は，大気状態不安定に起因する降雨で あり，降り始めから降り終わりまでが30分程度といった 非常に短時間の豪雨である. 都市中小河川では，このよ うな短時間強雨による内水被害等が増加しているため, 詳細な降雨波形の把握が重要であり，XバンドMPレー ダ雨量1分值を用いることで10分值と比べてピーク降雨 量やピーク雨量生起時刻を高い精度で把握することが可 能であると考えられる.

\section{5. むすび}

本論文では，Xバンド MP レーダ雨量について，神田 川上流域を対象として，高密度に配置された 1 分值地上 雨量観測データを用いて精度評価を実施した。 その結果, $\mathrm{X}$ バンドMP レーダ雨量の 1 分值データは, 十分に高い
精度を有しており，中小河川流域における空間分布，時 間分布ともに高精度に表現可能な降雨データであること を確認した. また，10 分值データではピーク雨量およ びその生起時刻を正確にとらえきれないが，X バンド MP レーダの 1 分值データを用いることで詳細な降雨を 把握することが可能である. 今後は，Xバンド MP レー ダによる詳細な降雨データをもとに，中小河川流域にお ける流出現象や河道水位，浸水や内水等の推定に活用し ていくことが必要である，それとともに，降雨の時空間 分布が流域に及ぼす影響を分析し，対象とする流域や河 川に対して必要となる降雨データの空間分解能や時間分 解能を明確にしておくことが求められる. また，そのた めにはより観測単位の細かい地上雨量観測データによる 検証も必要である.

\section{参考文献}

1) 天口英雄, 河村明, 高崎忠勝 : 地物データGISを用いた新 たな地物指向分布型都市洪水流出解析モデルの提案，土木学 会論文集 B,Vol.63,No.3,pp.206-223,2007.

2) 高崎忠勝, 河村明, 天口英雄, 荒木千博 : 都市の流出機構 を考慮した新たな貯留関数モデルの提案，土木学会論文集 B,Vol.65,No.3,pp.217-230,2009.

3) 土屋修一, 川崎将生, 五道仁実 : 降雨減衰補正と合成雨量 作成手法の改良のよるXRAIN観測雨量の精度向上，土木学 会論文集B1(水工学),Vol.71,No.4,Pp.I_457-I_462,2015.

4) 五道仁実, 内藤正彦，土屋修一: Kdp-R関係式の適用範囲拡 張によるXバンドMPレーダの観測精度の向上、土木学会論 文集B1(水工学),Vol.70,No.4,pp.I_505-I_510,2014.

5) 土屋修一, 川崎将生, 深見和彦, 根本深, 内藤正彦, 五道仁 実 : 降雨・洪水予測技術の高度化に向けたレーダ雨量情報の 高度化と活用の動向，河川技術論文集20巻,pp.343-348,2014.

6) 林義晃, 手計太一, 山剖准義 : 北陸地方における地上雨量観 測所を用いたXバンドMPレーダの降水量（降雪量）推定精 度の評価, 水文・水資源学会誌,Vol.27,No2,Mar.2014,pp.67$76,2014$.

7) 庄建治朗, 谷口健司, 冨永晃宏 : 10分雨量データとXRAIN データを用いた名古屋における強雨事例の雨域特性解析，土 木学会論文集B1(水工学),Vol.70,No.4,pp.I_487-I_492,2014.

8) 林義晃, 手計太一, 永島健, 山㟝惟義 : 北陸地方におけるX バンドMPレーダの降水量推定精度に関する時空間分布特性, 水文・水資源学会誌,Vol.28,No5,Mar.2015,pp.221-232,2015.

9) 原田守博, 羽澄貴史 : XバンドMPレーダ情報に基づく局地 的短時間豪雨の雨域性状の確率論的評価, 土木学会論文集 B1(水工学),Vol.70,No.4,pp.I_511-I_516,2014.

10）健全な水循環系構築に関する関係省庁連絡会議 : 神田川 流域水循環系再生構想検討報告,p.2,2003.

11) 岡田博至, 田中岳 : 洪水時における降雨時系列の特性に 関寸る研究，平成13年度土木学会北海道支部,論文報告集,第 58号,pp.350-353,2001.

(2015. 9. 30受付) 